President Wilson's policy from an idealistic point of view, there are some who believe that he has set up an impracticable standard for Mexico, and others, relying upon the doctrine that internal changes in a state do not affect its international position, assert that the President's course is not well founded in international law and that he has confused the recognition of new states with the recognition of new governments.

Without attempting to support or refute either of these arguments or to justify or criticise the President's policy, an examination of the historical attitude of the United States towards Latin-American countries under similar circumstances seems to show that he is not attempting to inject into the present case new or impracticable principles of his own. Precedents may be found for his refusal to recognize General Huerta, for the sending of a confidential agent into the country and for his warning to Americans to leave the country. They appear to show that the principles which President Wilson is now invoking and the policy he has seen fit to pursue have been applied and followed in the past in the relations of the United States with Latin America. (See Moore's Digest of International Law, Vol. I, pp. 138-168.)

\title{
COUNT TADASU HAYASHI
}

Count Tadasu Hayashi, one of the most distinguished of contemporary Japanese diplomatists, died in Tokyo, July 10th last, in his sixtythird year, the sequel to a painful accident. His career forms an intimate part of the Meiji epoch in Japanese history. At the age of seventeen, two years before the Restoration, he was one of the first group of Japanese students sent to England by the Tokugawa Shogunate, for the purpose of studying the principles and methods of Occidental civilization. Recalled two years later, because of the outbreak of the civil war, Hayashi joined the forces of Admiral Viscount Inomoto, who established headquarters at the Hokkaido, where for a time he withstood the Imperial army. Obliged to surrender shortly, Hayashi with others was imprisoned. Later released, the young man taught English for a time in a private school in Yokohama, and subsequently became a translator at the American legation. In 1871 Count Mutsu was appointed governor of Kanagawa-ken, and Hayashi became his chief secretary. Thus began his official service under the Meiji government, a service which continued, with brief occasional interruptions, until 
his death, with a steady augmentation of influence and power. Very shortly he was transferred to the Foreign Office, and later attached to the suite of Prince Iwakura, the first foreign envoy ever sent out by Japan. Others in the suite were Prince Ito and Prince Okubo; and the most notable group of statesmen ever sent abroad by Japan made a memorable tour of the United States and Europe.

Upon his return, Count Hayashi was made governor of Hyogo-ken; and in 1891 he became Vice Minister for Foreign Affairs under Count Mutsu. In 1896, he was placed in charge of the legation at Peking. Later he was sent by his government to represent it at St. Petersburg, and still later he succeeded Baron Kato as the Minister to Great Britain. Returning again to the Foreign Office for a time, he was sent again to London after the war with Russia, as Japan's first Ambassador to Great Britain. He was recalled in 1906 to assume the post of Minister of Foreign Affairs and premier of the government. Resigning with his colleagues in 1908, Count Hayashi again became a member of the cabinet in 1911, when Marquis Saionji formed his third ministry, this time as Minister for the Department of Communications, which post he recently resigned, with his colleagues, upon another change of government.

Undoubtedly the greatest service which Count Hayashi rendered his country, and that for which he will be most honored in the history of Japan, was in connection with the negotiation of the treaty between Japan and Great Britain, known as the Anglo-Japanese Alliance, while he was the Japanese Minister at the Court of St. James. It was an instrument which has affected the future diplomatic relations between the Occident and the Orient more potentially, perhaps, than any treaty yet made; and it is the large part which Count Hayashi played in this difficult negotiation which insures his permanent place in the roll of Japanese statesmen and in the diplomatic history of the world.

Count Hayashi was not only an astute and successful diplomatist, but a student of remarkable attainments, and of fine literary tastes. While in England, he translated a history of Italy, and at a later date, he translated Mill's Political Economy. His subsequent writings embody many contributions to the history of the early days of the Meiji era. His career furnishes another instance of the debt which Japan owes to those of her sons who qualified themselves for their service to the nation by educational training either in Europe or the United States. 